Neurosurg Focus 23 (3):E12, 2007

\title{
Nelson syndrome: historical perspectives and current concepts
}

\author{
Mark Hornyak, M.D., ${ }^{1}$ Martin H. Weiss, M.D., ${ }^{2}$ Don H. Nelson, M.D., ${ }^{3}$ \\ and William T. Couldwell, M.D., Ph.D. ${ }^{1}$ \\ Departments of ${ }^{1}$ Neurosurgery and ${ }^{3}$ Medicine, University of Utah, Salt Lake City, Utah; and \\ ${ }^{2}$ Department of Neurological Surgery, University of Southern California, Los Angeles, California
}

\begin{abstract}
$\checkmark$ The appearance of an adrenocorticotropic hormone (ACTH)-producing tumor after bilateral adrenalectomy for Cushing disease was first described by Nelson in 1958. The syndrome that now bears his name was characterized by hyperpigmentation, a sellar mass, and increased plasma ACTH levels. The treatment of Cushing disease has changed drastically since the $1950 \mathrm{~s}$, when the choice was adrenalectomy. Thus, the occurrence, diagnosis, and treatment of Nelson syndrome have changed as well. In the modern era of high-resolution neuroimaging, transsphenoidal microneurosurgery, and stereotactic radiosurgery, Nelson syndrome has become a rare entity. The authors describe the history of the diagnosis and treatment of Nelson syndrome. In light of the changes described, the authors believe this disease must be reevaluated in the contemporary era and a modern paradigm adopted. (DOI: $10.3171 / F O C-07 / 09 / E 12)$
\end{abstract}

\section{KeY Words • Cushing disease • Cushing syndrome • Nelson syndrome • neurosurgery history}

$\mathrm{I}$ N 1958, Nelson et al. ${ }^{72}$ first described the appearance of an ACTH-producing tumor after bilateral adrenalectomy for Cushing disease. Dr. Don H. Nelson (Fig. 1) was a fellow in endocrinology and had already done considerable basic research in adrenal physiology when he initially reported the syndrome that now bears his name. In the original paper, the authors indicated that the syndrome was characterized by hyperpigmentation, sellar mass demonstrated by an enlarged sella turcica on skull radiographs, and increased plasma ACTH levels. ${ }^{72}$ Two years later, Nelson and colleagues ${ }^{73}$ had compiled the information obtained in nine additional patients with the same characteristics and findings as the patient in the initial case description. This clinical syndrome was initially known as postadrenalectomy syndrome but by 1962 became known as Nelson syndrome. ${ }^{56}$ Although the early definitions of this syndrome are paramount in the history of Nelson syndrome, the complete story involves the history of the treatment and diagnosis of Cushing disease and Dr. Nelson's contributions to the fields of endocrinology and neurosurgery.

Abbreviations used in this paper: $\mathrm{ACTH}=$ adrenocorticotropic hormone; $\mathrm{MR}=$ magnetic resonance.

\section{History of Cushing Disease}

The earliest published link between the clinical condition caused by hypercortisolemia and the adrenal gland was written by Guthrie and d'Este in 1907..35 Two years later, in an oration entitled "The hypophysis cerebri," Cushing 25 began to explain the endocrinological functions of the pituitary gland. At this early date, acromegaly was known to be caused by a pituitary tumor, but it was not known that hypercortisolemia had a similar cause. In 1912, Cushing ${ }^{26}$ described his patient, Miss M. G., in his book, The Pituitary Body and Its Disorders. Cushing hypothesized that, as in acromegaly, the hypercortisolemic syndrome might have been due to "a primary malady of the ductless glands." Two years later, in 1914, Sargent removed an adrenal tumor in a patient of Dr. Gordon Holmes', thereby curing the patient of this disease and establishing a definitive link between hypercortisolemia and adrenal tumors. ${ }^{41}$

Although a link between hypercortisolemia and adrenal tumors was apparent, cases of the hypercortisolemic syndrome in which an adrenal tumor was absent were being published as early as 1924.41,44 This included, in 1926, Weber's case report ${ }^{91}$ of a patient with the hypercortisolemic syndrome and a pituitary tumor, which, however, went without notice. Additional reports followed, and, in 1930, Viennese pathologist Julius Bauer ${ }^{7}$ published the case of a 


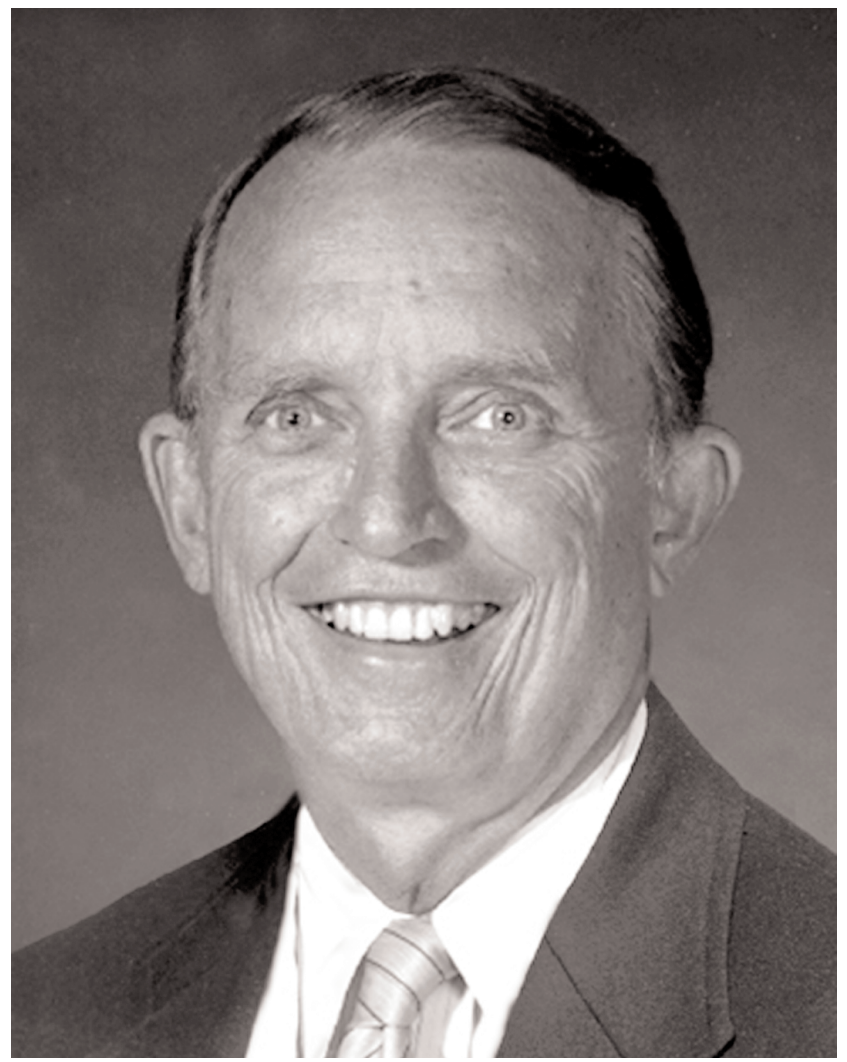

FIG. 1. Recent photograph of Dr. Don H. Nelson, M.D.

patient with hypercortisolemic syndrome without evidence of adrenal disease. Cushing read Bauer's report and recommended that he reexamine the pituitary gland. The specimen was found to have a basophilic pituitary tumor., ${ }^{6,63}$ At about the same time, Cushing published his landmark work on basophilic adenomas of the pituitary body ${ }^{24}$ and the clinical syndrome of hypercortisolemia, which soon came to be known as "Cushing syndrome."12

Despite the mounting evidence linking hypercortisolemia and pituitary tumors, ${ }^{64}$ microadenomas were difficult to diagnose, and transsphenoidal surgery was not popular at this time. Thus, the condition was usually considered to be a metabolic disorder caused by increased adrenal gland hormone secretion. ${ }^{2}$ Additional doubts regarding the link between hypercortisolemia and pituitary tumors developed after the authors of an autopsy study reported in 1935 that $7 \%$ of normal (nonhypercortisolemic) pituitary specimens contained a basophil adenoma. ${ }^{22}$ A similar syndrome was found in a patient with a tumor of the thymus, which added to the confusion among the medical establishment. ${ }^{53}$ An antipituitary camp, led by Kepler, ${ }^{51}$ maintained the belief that the only cause of Cushing syndrome was adrenal disease. In fact, it was not until 1950, when Bauer ${ }^{6}$ published his paper, "The so-called Cushing's syndrome," that a real distinction was made between hypercortisolism caused by adrenal disease and that caused by a pituitary tumor. Bauer wrote that "Cushing's disease, therefore, is the association of the known clinical syndrome with 'pituitary basophilism.' Hence it is this association not the clinical syndrome that should bear the eponym 'Cushing's disease,"' but the distinction was not widely accepted until 1972. ${ }^{9}$
Because of the controversy and limited understanding of pituitary physiology and disease, adrenalectomy was most often the primary treatment of Cushing syndrome at the time Nelson and colleagues initially described the syndrome of ACTH hypersecretion. Pituitary surgery was usually reserved for cases involving visual loss and was performed almost exclusively with craniotomy. At that time, it was known that Cushing syndrome was attributable to excess adrenal steroids in the blood, ${ }^{47}$ that this excess was unhealthy, and that adrenalectomy improved the clinical syndrome and extended the life expectancy of patients with this disease. Although there are scattered reports of cases of Cushing disease that were successfully treated with pituitary surgery (the earliest in 1933 by Dr. Naffziger ${ }^{58}$ ), pituitary surgery undertaken to treat endocrinological disorders was not truly accepted until after transsphenoidal microsurgery was reintroduced to the neurosurgical community by Jules Hardy in $1971,{ }^{31}$ and Tyrrell et al..$^{90}$ and Salassa et al. ${ }^{84}$ reported the cure of hypercortisolemia with the removal of microadenomas in their respective surgical series of 1978 .

\section{History of Nelson Syndrome}

Until the 1950s, only rather primitive mechanisms were available for evaluating adrenal cortical function. Despite the fact that Dr. Thomas Addison ${ }^{1}$ had described the syndrome of adrenal insufficiency in 1855, little was known about the hormones involved. While he was a research fellow, and later as a postdoctoral fellow at the University of Utah in the 1940s, Nelson and his colleagues working in Leo Samuels's laboratory endeavored to discover and quantify the adrenal steroids in human blood and serum. ${ }^{89}$ The specific steroid to be measured remained unknown until 1953. ${ }^{83}$ In 1950, Nelson and Samuels (Fig. 2) published a paper in which they described the process for isolating a steroid hormone from the blood of dogs. ${ }^{74}$ The availability of the "Nelson-Samuels" method allowed the accelerated pursuit of the physiology of adrenocortical secretions, ${ }^{10,11,33,75}$ including the ability to measure corticosteroids in human blood. ${ }^{76}$ Nelson was drafted into military service in 1952 and continued his research at the Naval Medical Research Institute in Bethesda. He continued to study adrenal physiology, and in 1955 he, along with his colleague David Hume, reported a method they had developed to determine the concentration of ACTH in human serum. ${ }^{71}$ This test was a bioassay in which they used hypophysectomized dogs. It was rather crude by modern standards, but significantly elevated levels of ACTH could be determined. Nelson then used this assay while serving as a house officer and research fellow at the Peter Bent Brigham Hospital in Boston to study the physiology in Cushing syndrome, especially in cases in which no pituitary or adrenal tumor could be found. This was the only assay available to measure ACTH, and it was used in the first reported case of hyperpigmentation, elevated serum ACTH level, and pituitary tumor as well as visual loss in a patient who had undergone adrenalectomy for Cushing syndrome. It was this postadrenalectomy syndrome that later became known as Nelson syndrome (the pituitary tumor was often called a Nelson tumor).

In 1958, Nelson and colleagues ${ }^{72}$ reported in the $\mathrm{New}$ 


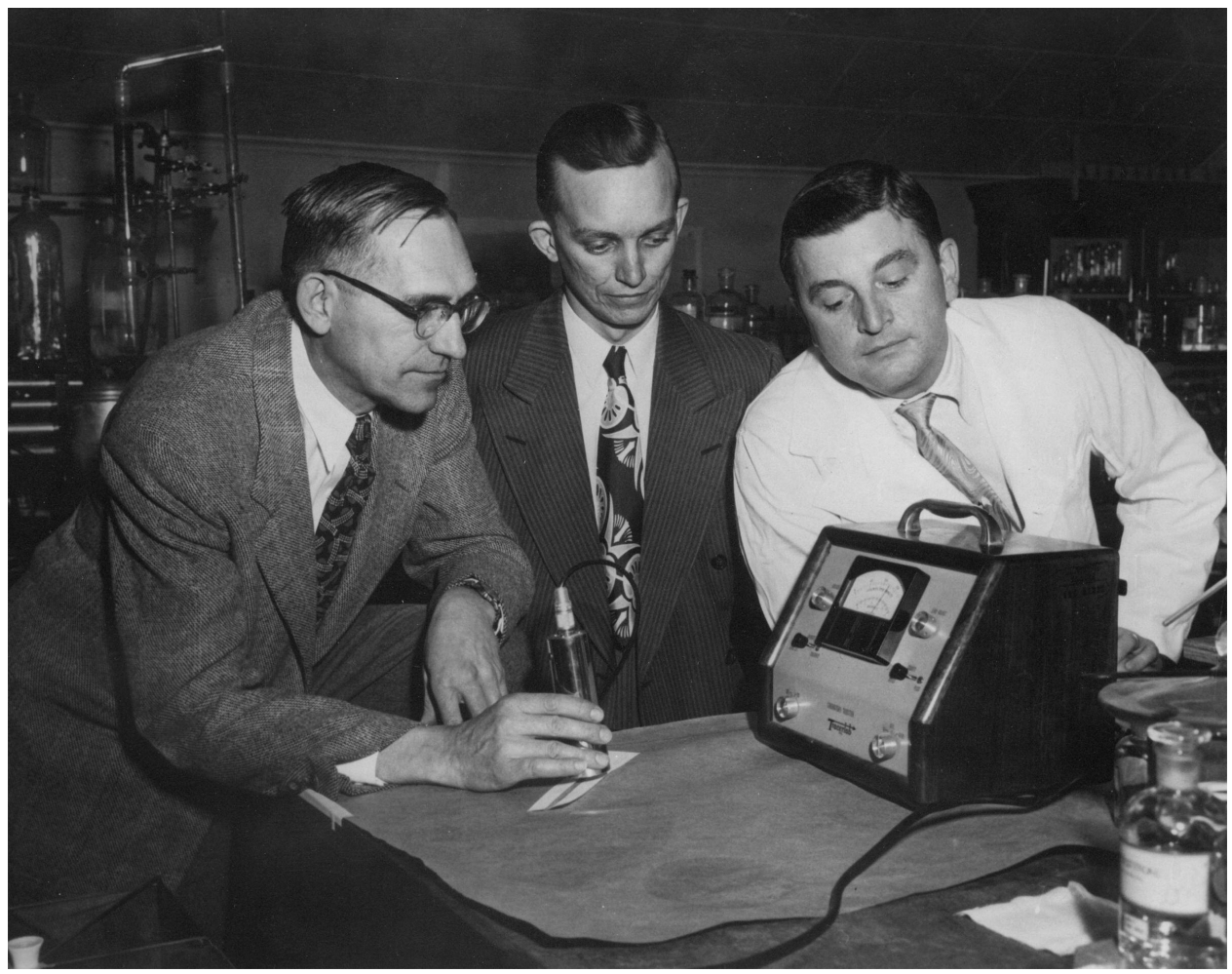

FIG. 2. Photograph of Dr. Nelson (center) and Dr. Leo Samuels (left), circa 1950, in the biochemistry laboratory at the University of Utah.

England Journal of Medicine (Fig. 3) the case of their 33year-old woman, "C.R." She had initially presented in 1954 with a 1-year history of nervousness, weakness, leg cramps, amenorrhea, acne, hirsutism, deepened voice, abdominal striae, polydipsia, and polyuria. On physical examination, she was observed to be obese, with a moon face, acne, mild hirsutism, and multiple ecchymoses and abdominal striae. She was hypertensive, her visual fields were normal, and her pituitary fossa size was "at the upper limits of normal" on a skull x-ray film. Laboratory studies revealed that she had glycosuria and hyperglycemia as well as an elevated level of 17-hydroxycorticosteroids in her urine. One month after her initial presentation, the patient underwent bilateral adrenalectomy. Her adrenal glands were normal in weight, but hyperplasia was demonstrated histologically. Postoperatively, she was placed on a daily regimen of 50 mg of cortisone. After 2 months, her symptoms had resolved, her endocrinological levels were normal, and she began to menstruate normally. Two years later, she complained of menorrhagia and cutaneous pigmentation, but no other abnormalities were found, and her serum glucose level remained normal.

In 1957, 3 years after her initial presentation, the patient began to suffer renewed amenorrhea and progressive loss of vision in her left eye. On examination, her skin was found to be deeply pigmented (Fig. 4), and she had a nearly complete bitemporal hemianopsia. Examination of laboratory studies showed that the level of 17-hydroxycorticosteroids was normal, but the level of ACTH exceeded 200 $\mathrm{mU} / 100 \mathrm{ml}$ (normal levels were undetectable using the Nelson-Hume method). A radiographic workup, including skull radiographs, laminagrams, and a fractional air study, now demonstrated expansion of the sella turcica with destruction of the dorsum sellae and the presence of a suprasellar tumor. Radiotherapy was initiated, but after 24 treatments hemorrhage into the tumor suddenly occurred. Because of the apoplexy, the patient was taken to the operating room where she underwent urgent decompression via craniotomy. A soft, hemorrhagic tumor was resected without complication, and she recovered well. Her vision improved, and her ACTH level became undetectable. She underwent monitoring for an additional 18 weeks. During this time, her cutaneous pigmentation subsided (Fig. 4) and her ACTH remained low, similar to that of other patients with hypoadrenocorticism. ${ }^{11}$

In discussing this case, Nelson first debated the possibility of two causes of Cushing syndrome: one of adrenal and one of pituitary origin. He stated that a pituitary tumor should elevate the serum ACTH level but admitted that his "methods for the determination of ACTH in plasma are generally not sensitive enough" to determine moderately increased levels. He also surmised that the patient might have had an ACTH-secreting pituitary tumor and that "the removal of the adrenal glands may have acted as a stimulus to the pituitary gland, with growth of the tumor and increased secretion of ACTH resulting." Finally, he concluded that "development of a pituitary tumor is a possible sequela of bilateral adrenalectomy for Cushing's syndrome."

Because many adrenalectomies were being performed, it became increasingly evident that, in a certain population of patients, adrenalectomy caused the clinical syndrome of 
M. Hornyak et al.

\title{
ACTH-PRODUCING TUMOR OF THE PITUITARY GLAND*
}

\author{
Don H. Nelson, M.D.,† J. W. Meakin, M.D., J James B. Dealy, JR., M.D. \$ \\ Donald D. Matson, M.D., K Kendall Emerson, Jr., M.D., || and George W. Thorn, M.D.** \\ BOSTON
}

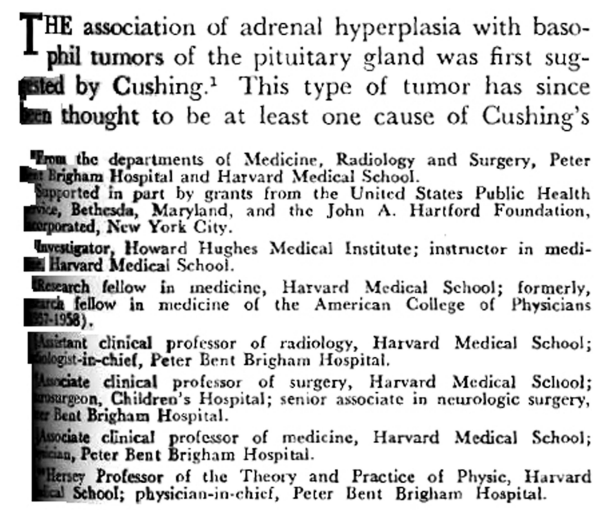

syndrome, but no demonstration of elevated levels of ACTH has been reported in the plasma of patients with this condition. The case described below is that of a patient who, three years after bilateral adrenalectomy for hyperadrenocorticism, was found to have a chromophobe tumor of the pituitary gland that was secreting large quantities of ACTH.

\section{Case Report}

C.R. (P.B.B.H. 9G418), a 33-year-old married woman of Italian extraction, was first admitted to the Peter Bent Brig ham Hospital on August 17, 1954. The family and past histories wcre noncontributory. Two pregnancies 9 and 10 years previously had been essentially normal. Presenting symptoms (from 1 to 12 months in duration) included nervousness, weakness, leg cramps, amenorrhea, acne, hirsutism, deepened voice, obesity, rounding of the face, increased bruisability, abdominal striae, polydipsia and polyuria.

FIG. 3. The title page of the case report in which the authors described the initial identified case of the syndrome that came to be known as Nelson syndrome.

hyperpigmentation and pituitary tumor (Nelson syndrome). It was believed by many that the removal of the adrenal glands caused the de novo formation of a pituitary tumor. When testing for serum ACTH levels became available, ${ }^{71,79}$ Nelson was able to report the abnormally high levels of this hormone after adrenalectomy. ${ }^{77}$ By 1960 , he had identified 10 patients with this "post-adrenalectomy" syndrome. ${ }^{73}$ In this second paper on the syndrome (Fig. 5), Nelson made three notable observations. First, he discovered the suppressibility of ACTH secretion in patients with pituitary tumors after they were given hydrocortisone therapy. Second, he described a patient who suffered from Cushing syndrome and was found to have an elevated ACTH level but no evidence of a pituitary tumor. This patient underwent a partial adrenalectomy, which led to a remission of the Cushing syndrome, but later suffered recurrence of the Cushing syndrome, an increased ACTH level, and a sellar tumor but no hyperpigmentation. Nelson himself remarked, "It has not been possible with the present technic [sic] to detect normal circulating levels of plasma-ACTH, and therefore a slight elevation of ACTH above 'normal' would presumably not be detected by the assay procedure used." Six years later he reported the elevation of ACTH in a patient with Cushing syndrome and a pituitary tumor before any treatment, foreshadowing the importance of this test in the determination of a pituitary source of Cushing syndrome. ${ }^{77}$ Because of their low sensitivity, serum ACTH assays could not be used routinely to differentiate pituitarydependent from primary hypercortisolemia until much later. Last, Nelson concluded that in patients presenting with postadrenalectomy pituitary tumors, the evidence "strongly suggests either that the tumor was present prior to bilateral adrenalectomy, or that there was some abnormal stimulus to the pituitary gland which may have acted to produce the pituitary adenoma in these particular cases." This again highlights the uncertainty of the causes of Cushing syndrome into the 1960s.

Given the confusion over the cause, the typical treatment paradigm for Cushing syndrome of the 1950s and into the 1970s - the use of adrenalectomy-was targeted at the final common pathway, regardless of the cause of the hypercortisolemia. ${ }^{28}$ Irradiation of the sella was sometimes performed, ${ }^{65}$ and hypophysectomy was generally considered if there were overt signs of a sellar tumor, usually in association with a patient's loss of vision. Given the fact that there was still a great deal of controversy surrounding the cause of Cushing syndrome, there was no standard of care.

\section{Nelson and Cushing Syndromes in the Modern Era}

The development of Nelson syndrome after adrenalectomy for Cushing syndrome has been reported in between 8 and $47 \%$ of cases. $4,15,16,19,28,30,45,48-50,62,65,68,80,87,95$ These numbers vary depending on the extent of adrenalectomy, the causes of the hypercortisolemia in the treated patients, and the year the surgery was performed. As endocrinological, radiological/imaging, and neurosurgical advances were made in the understanding of and ability to diagnose the causes of Cushing syndrome and the modes of therapy, management of both Cushing and Nelson syndromes moved into the modern era.

The advances in endocrinology led to a better ability to diagnose Cushing disease and differentiate its various causes. The first development, as described above, was the ability to measure corticosteroid ${ }^{76}$ and $\mathrm{ACTH}^{71}$ levels in human blood samples. In part because of the observations made by Nelson in 1960, the low- and high-dose dexamethasone suppression tests became available to differentiate adrenaland pituitary-dependent hypercortisolemia. Liddle ${ }^{55}$ reported that the abnormally elevated levels of urinary corticosteroids were suppressed in all patients with a known pituitary tumor by high doses of dexamethasone ( $2 \mathrm{mg}$ every 6 hours) but not with low doses ( $0.5 \mathrm{mg}$ every 6 hours). Individuals with a known adrenal tumor were completely resistant to high and low doses of the drug. This was the first reliable test to differentiate among the causes of Cushing syndrome. Although this test offered improved 


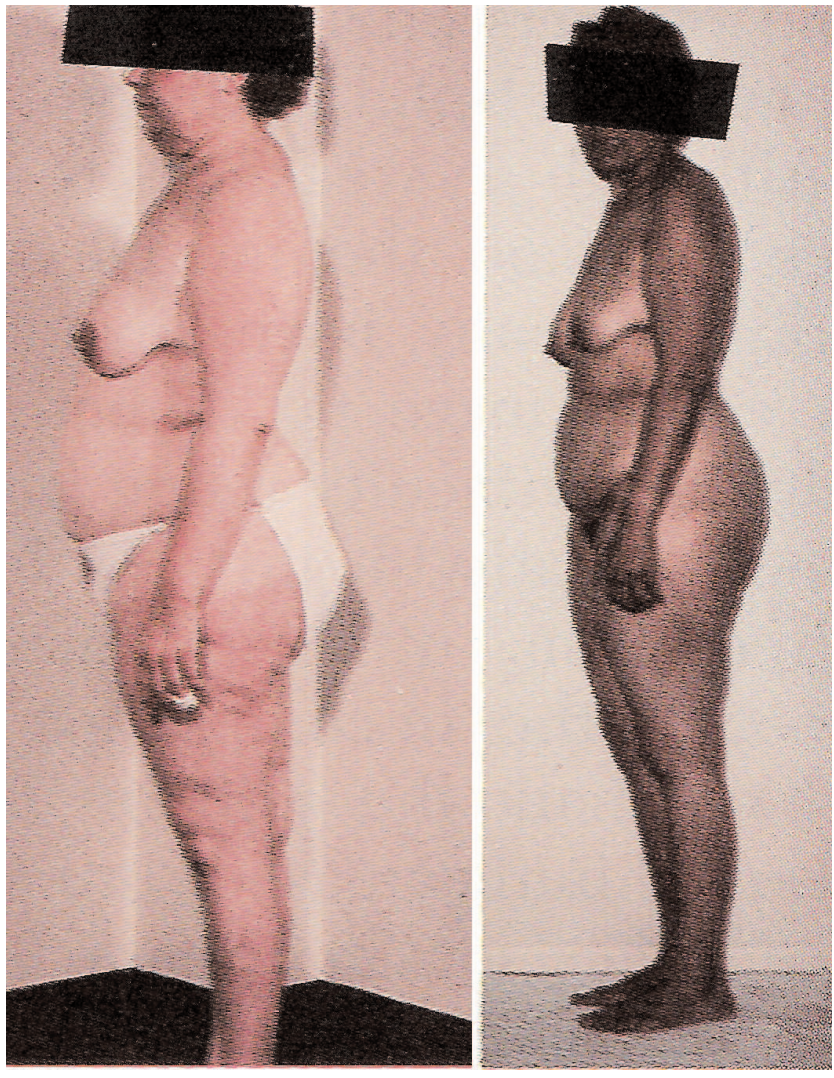

FIG. 4. Photographs of Patient C.R., the first reported case of Nelson syndrome, before (left) and after (right) adrenalectomy for Cushing disease. Note the features of Cushing disease preoperatively and the skin pigmentation after. Adapted with permission from Nelson DH, The Adrenal Cortex, W. B. Saunders, 1980.

ability for differentiation because it was somewhat specific, it was not very sensitive, as many patients tested equivocally. ${ }^{54,93}$ Therefore, again following the lead of Nelson, the assay for the determination of ACTH in plasma was refined. With the production of specific antibodies, ${ }^{31} \mathrm{a}$ radioimmunoassay could be performed. In 1964, Yalow et al. ${ }^{97}$ reported the results of an assay for ACTH that required less than $0.2 \mathrm{ml}$ of serum and had a sensitivity as low as $0.06 \mathrm{mU} / 100 \mathrm{ml}$, approximately 100 -fold more sensitive than Nelson's bioassay. ${ }^{77}$ This allowed the detection of mildly elevated ACTH levels that could be caused by a pituitary microadenoma. With the advent of stimulation testing with corticotropin-releasing factor, the ability to distinguish the different causes of Cushing syndrome became even more widely available. ${ }^{67}$

Several advances in radiography and neuroimaging also led to a change in the differential diagnosis of Cushing syndrome. A patient with Cushing syndrome or hyperpigmentation after adrenalectomy was typically screened with radiographs of the skull only. ${ }^{92}$ In 1973, the computed tomography scanner was introduced to clinical medicine ${ }^{42}$ and was soon used to obtain images of the brain and sella turcica. ${ }^{3,69,78}$ This was soon followed by the development of MR imaging in the late 1970s..$^{23,27,38,43,66}$ The computed tomography and MR imaging findings correlated with surgical findings in 42 and $52 \%$ of cases of ACTH-secreting microadenomas, respectively. ${ }^{17}$ High field strength MR imagers and dynamic imaging techniques have improved the sensitivity in recent years. ${ }^{13}$ Last, the invasive endovascular technique of inferior petrosal sinus sampling was developed, ${ }^{21}$ yielding very high sensitivity and specificity in cases of pituitary-dependent Cushing disease.,59

The last advances to consider in the recent developments in management of Cushing disease are the contributions of neurosurgeons. Pituitary surgery was initially attempted in 1893 by Caton and Paul ${ }^{18}$ in a patient with acromegaly. It soon became apparent to the neurosurgical community, however, that pituitary surgery was a morbid endeavor and therefore its use was largely abandoned, except in the most extreme cases, which were treated with transcranial operations. ${ }^{60}$

The earliest reported successful pituitary surgery for microadenoma-related Cushing disease was conducted in 1933 (but not published until 1944), ${ }^{58}$ yet most patients with Cushing syndrome and a pituitary tumor underwent sellar radiotherapy and adrenalectomy; the adrenalectomy treated the hypercortisolemia and the radiotherapy successfully controlled the growth of most of these tumors. ${ }^{14,46}$ With improvements in antibiotic therapy and intraoperative technology (including instrumentation, operative microscopy and microsurgery, and fluoroscopy), transsphenoidal pituitary surgery slowly gained acceptance, largely because of the work of Jules Hardy ${ }^{36}$ As pituitary surgery became more widely accepted, it was used successfully to treat Cushing disease but was still not considered the standard of care into the 1980s. For instance, there was debate over the effectiveness of prophylactic sellar irradiation in the prevention of Nelson syndrome. ${ }^{45,57,65}$ In 1980, Nelson wrote in an editorial, "in those patients who fail to be cured adequately by the transsphenoidal approach, irradiation should be considered.' 70

These advancements associated with improved management of Cushing syndrome also apply to the diagnosis and treatment of Nelson syndrome. Currently, measurement of $\mathrm{ACTH}$ is a reliable and routine laboratory investigation that is widely available. Even minor elevations in ACTH levels can be identified after adrenalectomy, and further investigations can be performed. Serial imaging after treatment for Cushing disease is now routine. Initially, the sella was imaged only with skull radiography, ${ }^{92}$ but current MR imaging systems can detect small-size tumors. ${ }^{52}$ Similarly, the surgical treatment of Nelson tumors has evolved. The earliest report of pituitary surgery for Nelson syndrome was published by Espinoza et al..$^{29}$ in 1973, who performed surgery in three patients via a transsphenoidal approach and were able to normalize the ACTH in two and reduce the level in the third patient postoperatively; no more than immediate results were reported.

Although the authors of early series found only limited success after transsphenoidal pituitary surgery for Nelson syndrome (27\% success), ${ }^{94}$ the authors of later reports showed somewhat better outcomes (success rate range 46-80\%). ${ }^{32,50,95}$ As with other tumors of the pituitary, residual or recurrent tumors can be treated with stereotactic radiosurgery. ${ }^{96}$

The current treatment paradigm for Cushing disease includes aggressive treatment with therapies directed at the pituitary tumor. Resection is the primary treatment modal- 


\title{
A METHOD FOR THE DETERMINATION OF 17- HYDROXYCORTICOSTEROIDS IN BLOOD: 17- HYDROXYCORTICOSTERONE IN THE PERIPHERAL CIRCULATION*
}

\author{
DON H. NELSON, M.D.† AND LEO T. SAMUELS, Ph.D. \\ From the Department of Biochemistry, University of Utah College of Medicine, \\ Salt Lake City, Utah
}

\begin{abstract}
$\mathrm{A}^{\mathrm{D}}$ DRENAL steroid activity has been demonstrated in adrenal venous blood by means of biologic assay $(1,2)$. The biologic techniques, although successful in demonstrating the presence of adrenal steroids, have been unsatisfactory from a quantitative standpoint and have given little information regarding the specific compound being measured. Chemical methods for the determination of adrenal steroids in blood have been proposed by Corcoran and Page (3), and by Porter and Silber (4).

The method of Corcoran and Page was found to give high values due to the formation of formaldehyde from phospholipids, traces of which could not be eliminated even by repeated precipitation with acetone. The color reaction of Porter and Silber depends on the formation of phenylhydrazones in acid solution. Under the conditions given, the 17,21-dihydroxy20-ketosteroids showed a strong maximum absorption at $410 \mathrm{~m} \mu$ when several steroid ketones were tested. The purification procedure used with plasma, however, was so nonspecific as to raise the question of the influence of other compounds on the reaction.

The present communication deals with the development of a method for the quantitative estimation of 17 -hydroxycorticosteroids in peripheral blood; using the color reaction described by Porter and Silber. The chief compound measured is apparently 17 -hydroxycorticosterone ${ }^{1}(5)$.
\end{abstract}

FIG. 5. The title page taken from Dr. Nelson's first series of patients with the postadrenalectomy syndrome, which later became known as Nelson syndrome.

ity and can lead to biochemical cure in 74 to $78 \%$ of cases. ${ }^{20,86}$ Reoperation should be considered in cases of accessible residual or recurrent tumor, including total hypophysectomy. ${ }^{8,61}$ For unresectable disease (that is, cavernous sinus invasion), radiation can be delivered via conventional means or using conformal techniques..$^{85}$ Adrenalectomy should be considered only after therapy directed at the pituitary gland has failed. After adrenalectomy, patients must be carefully observed with serial MR imaging and laboratory investigations. The use of prophylactic sellar irradiation in the cases of persistent hypercortisolemia and without the demonstration of pituitary adenoma is controversial. ${ }^{34}$

\section{Conclusions}

Thus, all the pieces came together to bring Cushing syndrome into the contemporary era. The different causes of this syndrome can be diagnosed with great accuracy, and microsurgical treatment directed at the pituitary is safe and effective in experienced hands..$^{20,39,82,86}$ The disease in few patients is refractory to multimodal therapy directed at the sella for pituitary-dependent Cushing disease, which includes surgery, conventional radiotherapy, stereotactic radiosurgery, ${ }^{81,85}$ and medical therapy. ${ }^{37}$ Thus, once it became apparent that pituitary tumors could cause hyper- cortisolemia and tests became available to diagnose the cause, the number of patients undergoing adrenalectomy in the modern era decreased, and even fewer are developing Nelson syndrome. In light of these considerations, we believe that Nelson syndrome should be reevaluated to determine the roles of surgery, radiotherapy, and radiosurgery in the modern era.

\section{Acknowledgment}

We thank Kristin Kraus, M.Sc., for her editorial assistance in preparing this paper.

\section{References}

1. Addison T: On the Constitutional and Local Effects of Diseases of the Supra-Renal Capsules. London: Samuel Highley, 1855

2. Albright F: Cushing's syndrome: its pathological physiology. Harvey Lect 38:123-186, 1943

3. Ambrose J: Computerized transverse axial scanning (tomography). 2. Clinical application. Br J Radiol 46:1023-1047, 1973

4. Assié G, Bahurel H, Bertherat J, Kujas M, Legmann P, Bertagna X: The Nelson's syndrome . . . revisited. Pituitary 7:209-215, 2004

5. Batista D, Gennari M, Riar J, Chang R, Keil MF, Oldfield EH, et al: An assessment of petrosal sinus sampling for localization of pituitary microadenomas in children with Cushing disease. J Clin Endocrinol Metab 91:221-224, 2006 
6. Bauer J: The so-called Cushing's syndrome, its history, terminology and differential diagnosis. Acta Med Scand 137:412-416, 1950

7. Bauer VJ: Ueberfunktion des gesamten Nebennieren systems ohne anatomischen Befund. Wein Klin Wochenschr 43: $582-585,1930$

8. Benveniste RJ, King WA, Walsh J, Lee JS, Delman BN, Post KD: Repeated transsphenoidal surgery to treat recurrent or residual pituitary adenoma. J Neurosurg 102:1004-1012, 2005

9. Besser GM, Edwards CRW: Cushing's syndrome. Clin Endocrinol Metab 1:431-490, 1972

10. Bethune JE, Despointes RH, Antoniades HN, Nelson DH: Corticotrophic activity of human plasma constituents. Proc Soc Exp Biol Med 97:69-72, 1958

11. Bethune JE, Nelson DH, Thorn GW: Plasma adrenocorticotrophic hormone in Addison's disease and its modification by the administration of adrenal steroids. J Clin Invest 36:1701-1707, 1957

12. Bishop PMF, Close HG: A case of basophil adenoma of the anterior lobe of the pituitary: "Cushing's Syndrome." Guy's Hosp Rep 82:143-153, 1932

13. Bonneville JF, Bonneville F, Cattin F: Magnetic resonance imaging of pituitary adenomas. Eur Radiol 15:543-548, 2005

14. Boucot N, Dohan FC, Raventos A, Rose E: Roentgen therapy in Cushing's syndrome without adrenocortical tumor. J Clin Endocrinol Metab 17:8-32, 1957

15. Brunicardi FC, Rosman PM, Lesser KL, Andersen DK: Current status of adrenalectomy for Cushing's disease. Surgery 98: 1127-1134, 1985

16. Buchfelder M, Fahlbusch R, Thierauf P, Müller OA: Observations on the pathophysiology of Nelson's syndrome: a report of three cases. Neurosurgery 27:961-968, 1990

17. Buchfelder M, Nistor R, Fahlbusch R, Huk WJ: The accuracy of $\mathrm{CT}$ and MR evaluation of the sella turcica for detection of adrenocorticotropic hormone-secreting adenomas in Cushing disease. AJNR Am J Neuroradiol 14:1183-1190, 1993

18. Caton R, Paul FT: Notes of a case of acromegaly treated by operation. Brit Med J 2:1421-1423, 1893

19. Chapuis Y, Pitre J, Conti F, Abboud B, Pras-Jude N, Luton JP: Role and operative risk of bilateral adrenalectomy in hypercorticolism. World J Surg 20:775-780, 1996

20. Chen JC, Amar AP, Choi S, Singer P, Couldwell WT, Weiss MH: Transsphenoidal microsurgical treatment of Cushing disease: postoperative assessment of surgical efficacy by application of an overnight low-dose dexamethasone suppression test. J Neurosurg 98:967-973, 2003

21. Corrigan DF, Schaaf M, Whaley RA, Czerwinski CL, Earll JM: Selective venous sampling to differentiate ectopic ACTH secretion from pituitary Cushing's syndrome. N Engl J Med 296: 861-862, 1977

22. Costello RT: Subclinical adenomas of the pituitary body. Mayo Clin Proc 10:449-453, 1935

23. Crooks LE, Grover TP, Kaufman L, Singer JR: Tomographic imaging with nuclear magnetic resonance. Invest Radiol 13: 63-66, 1978

24. Cushing H: The basophil adenomas of the pituitary body and their clinical manifestations (pituitary basophilism). Bull Johns Hopkins Hosp 50:137-195, 1932

25. Cushing H: The hypophysis cerebri: clinical aspects of hyperpituitarism and hypopituitarism. JAMA 53:249-255, 1909

26. Cushing H: The Pituitary Body and Its Disorders, Clinical States Produced by Disorders of the Hypophysis Cerebri. Philadelphia: JB Lippincott Co., 1912

27. Doyle FH, Gore JC, Pennock JM, Bydder GM, Orr JS, Steiner RE, et al: Imaging of the brain by nuclear magnetic resonance. Lancet 2:53-57, 1981

28. Ernest I, Ekman H: Adrenalectomy in Cushing's disease. A longterm follow-up. Acta Endocrinol Suppl (Copenh) 160:3-41, 1972
29. Espinoza A, Nowakowski H, Kautzky R, Lüdecke D: ACTH determinations before and after selective removal of pituitary adenomas in Nelson's syndrome. Acta Endocrinol Suppl (Copenh) 173:34, 1973

30. Favia G, Boscaro M, Lumachi F, D'Amico DF: Role of bilateral adrenalectomy in Cushing's disease. World J Surg 18:462-466, 1994

31. Felber JP: ACTH antibodies and their use for a radio-immunoassay for ACTH. Experientia 19:227-229, 1963

32. Fukushima T: Trans-sphenoidal microsurgical treatment of Nelson's syndrome. Neurosurg Rev 8:185-194, 1985

33. Gassner FX, Nelson DH, Reich H, Rapala RT, Samuels LT: Isolation of an androgenic compound from the adrenal venous blood of cows. Proc Soc Exp Biol Med 77:829-831, 1951

34. Gil-Cárdenas A, Herrera MF, Díaz-Polanco A, Rios JM, Pantoja JP: Nelson's syndrome after bilateral adrenalectomy for Cushing's disease. Surgery 141:147-152, 2007

35. Guthrie L, d'Este EW: Precocious obesity, premature sexual and physical development and hirsuties in relation to hypernephroma and other morbid conditions. Trans Clin Soc Lond 40:175-202, 1907

36. Hardy J: Transsphenoidal hypophysectomy. J Neurosurg 34: 582-594, 1971

37. Heaney AP: PPAR-gamma in Cushing's disease. Pituitary 7: 265-269, 2004

38. Hinshaw WS, Andrew ER, Bottomley PA, Holland GN, Moore WS: Display of cross sectional anatomy by nuclear magnetic resonance imaging. Br J Radiol 51:273-280, 1978

39. Hofmann BM, Fahlbusch R: Treatment of Cushing's disease: a retrospective clinical study of the latest 100 cases. Front Horm Res 34:158-184, 2006

40. Holland WL, Brozinick JT, Wang LP, Hawkins ED, Sargent KM, Liu Y, et al: Inhibition of ceramide synthesis ameliorates glucocorticoid-, saturated-fat-, and obesity-induced insulin resistance. Cell Metab 5:167-179, 2007

41. Holmes G: A case of virilism associated with a suprarenal tumor; recovery after its removal. Q J Med 18:143-152, 1925

42. Hounsfield GN: Computerized transverse axial scanning (tomography). 1. Description of system. Br J Radiol 46:1016-1022, 1973

43. Huk WJ, Fahlbusch R: Nuclear magnetic resonance imaging of the region of the sella turcica. Neurosurg Rev 8:141-150, 1985

44. Itsenko NM: Pituitary enlargement with a multiglandular symptom complex and a review of the problem of central innervation of the vegetative functions. Southeast Herald Pub Health 3-4:136, 1924

45. Jenkins PJ, Trainer PJ, Plowman PN, Shand WS, Grossman AB, Wass JA, et al: The long-term outcome after adrenalectomy and prophylactic pituitary radiotherapy in adrenocorticotropin-dependent Cushing's syndrome. J Clin Endocrinol Metab 80: $165-171,1995$

46. Johnsen SG: Roentgen irradiation of the pituitary in Cushing's syndrome, with a brief discussion of the pathogenesis of the syndrome. Acta Med Scand 144:165-188, 1952

47. Jores A: Uber Hormonuntersuchungen bei morbus Cushing. Klin Wochenschr 14:1348-1352, 1945

48. Kasperlik-Zaluska AA, Bonicki W, Jeske W, Janik J, Zglicynski W, Czernicki Z: Nelson's syndrome-46 years later: clinical experience with 37 patients. Zentrabl Neurochir 67:14-20, 2006

49. Kasperlik-Zaluska AA, Nielubowicz J, Wislawski J, Hartwig W, Zaluska J, Jeske W, et al: Nelson's syndrome: incidence and prognosis. Clin Endocrinol (Oxf) 19:693-698, 1983

50. Kelly PA, Samandouras G, Grossman AB, Afshar F, Besser GM, Jenkins PJ: Neurosurgical treatment of Nelson's syndrome. J Clin Endocrinol Metab 87:5465-5469, 2002

51. Kepler EJ, Sprague RG, Clagett OT, Power MH, Mason HL, Rogers HM: Adrenal cortical tumor associated with Cushing's syndrome. J Clin Endocrinol 8:499, 1948

52. Kucharczyk W, Bishop JE, Plewes DB, Keller MA, George S: 
Detection of pituitary microadenomas: comparison of dynamic keyhole fast spin-echo, unenhanced, and conventional contrastenhanced MR imaging. AJR Am J Roentgenol 163:671-679, 1994

53. Leyton O, Turnbull HM, Bratton AB: Primary cancer of the thymus with pluriglandular disturbance. J Path Bact 34:635-660, 1931

54. Liddle GW: Assessment of pituitary and adrenal function. Physiol Pharmacol Physicians 14:1-5, 1965

55. Liddle GW: Tests of pituitary-adrenal suppressibility in the diagnosis of Cushing's syndrome. J Clin Endocrinol Metab 20: 1539-1560, 1960

56. Liddle GW, Island D, Meador CK: Normal and abnormal regulation of corticotropin secretion in man. Rec Prog Horm Res 18:125-166, 1962

57. Linfoot JA, Chong CY, Garcia JF, Cleveland AS, Connell GM, Manougian E, et al: Heavy-particle therapy for acromegaly, Cushing's disease, Nelson's syndrome, and nonfunctioning pituitary adenomas. Prog At Med 3:219-238, 1971

58. Lisser H: Hypophysectomy in Cushing's disease. J Nerv Ment Dis 99:727-733, 1944

59. Liu C, Lo JC, Dowd CF, Wilson CB, Kunwar S, Aron DC, et al: Cavernous and inferior petrosal sinus sampling in the evaluation of ACTH-dependent Cushing's syndrome. Clin Endocrinol (Oxf) 61:478-486, 2004

60. Liu JK, Das K, Weiss MH, Laws ER, Couldwell WT: The history and evolution of transsphenoidal surgery. J Neurosurg 95:1083-1096, 2001

61. Locatelli M, Vance ML, Laws ER: Clinical review: the strategy of immediate reoperation for transsphenoidal surgery for Cushing's disease. J Clin Endocrinol Metab 90:5478-5482, 2005

62. McCance DR, Russell CF, Kennedy TL, Hadden DR, Kennedy L, Atkinson AB: Bilateral adrenalectomy: low mortality and morbidity in Cushing's disease. Clin Endocrinol (Oxf) 39:315-321, 1993

63. Medvei VC: The history of Cushing's disease: a controversial tale. J R Soc Med 84:363-366, 1991

64. Medvei VCV, Wermer P: Zur Differentialdiagnose des basophilen Adenoms der Hypophyse. Med Klinik 30:992-994, 1934

65. Moore TJ, Dluhy RG, Williams GH, Cain JP: Nelson's syndrome: frequency, prognosis, and effect of prior pituitary irradiation. Ann Intern Med 85:731-734, 1976

66. Moore WS, Holland GN: Nuclear magnetic resonance imaging. Br Med Bull 36:297-299, 1980

67. Muller OA, Dörr HG, Hagen B, Stalla GK, von Werder K: Corticotropin releasing factor (CRF)-stimulation test in normal controls and patients with disturbances of the hypothalamo-pituitary-adrenal axis. Klin Wochenschr 60:1485-1491, 1982

68. Nagesser SK, van Seters AP, Kievit J, Hermans J, Kraus HM, van de Velde CJ: Long-term results of total adrenalectomy for Cushing's disease. World J Surg 24:108-113, 2000

69. Naidich TP, Pinto RS, Kushner MJ, Lin JP, Kricheff II, Leeds NE, et al: Evaluation of sellar and parasellar masses by computed tomography. Radiology 120:91-99, 1976

70. Nelson DH: Therapy for acromegaly, Cushing disease and Nelson syndrome. West J Med 133:244-245, 1980

71. Nelson DH, Hume DM: Corticosteroid secretion in the adrenal venous blood of the hypophysectomized dog as an assay for ACTH. Endocrinology 57:184-192, 1955

72. Nelson DH, Meakin JW, Dealy JB Jr, Matson DD, Emerson K Jr, Thorn GW: ACTH-producing tumor of the pituitary gland. N Engl J Med 259:161-164, 1958

73. Nelson DH, Meakin JW, Thorn GW: ACTH-producing pituitary tumors following adrenalectomy for Cushing's syndrome. Ann Intern Med 52:560-569, 1960

74. Nelson DH, Reich H, Samuels LT: Isolation of a steroid hormone from the adrenal-vein blood of dogs. Science 111:578, 1950

75. Nelson DH, Reich H, Samuels LT: The effect of ACTH upon the level of 17-hydroxycorticosterone in the adrenal vein blood of dogs. J Clin Endocrinol Metab 10:810, 1950

76. Nelson DH, Samuels LT, Willardson, Tyler FH: The levels of 17hydroxycorticosteroids in peripheral blood of human subjects. J Clin Endocrinol Metab 11:1021-1029, 1951

77. Nelson DH, Sprunt JG, Mims RB: Plasma ACTH determinations in 58 patients before or after adrenalectomy for Cushing's syndrome. J Clin Endocrinol Metab 26:722-728, 1966

78. Ommaya AK: Computerized axial tomography of the head: the EMI-scanner, a new device for direct examination of the brain "in vivo.” Special article. Surg Neurol 1:217-222, 1973

79. Paris J, Upson M, Sprague RG, Salassa RM, Albert A: Corticotropic activity of human blood. J Clin Endocrinol Metab 14:597-607, 1954

80. Periera MA, Halpern A, Salgado LR, Mendonca BB, Nery M, Liberman B, et al: A study of patients with Nelson's syndrome. Clin Endocrinol (Oxf) 49:533-539, 1998

81. Post KD: Radiosurgery and Cushing's disease. J Neurosurg 93: 907-909, 2000

82. Reitmeyer M, Vance ML, Laws ER: The neurosurgical management of Cushing's disease. Mol Cell Endocrinol 197:73-79, 2002

83. Romanoff EB, Hudson P, Pincus G: Isolation of hydrocortisone and corticosterone from human adrenal vein blood. J Clin Endocrinol Metab 13:1546-1548, 1953

84. Salassa RM, Laws ER Jr, Carpenter PC, Northcutt RC: Transsphenoidal removal of pituitary microadenoma in Cushing's disease. Mayo Clin Proc 53:24-28, 1978

85. Sheehan JM, Vance ML, Sheehan JP, Ellegala DB, Laws ER: Radiosurgery for Cushing's disease after failed transsphenoidal surgery. J Neurosurg 93:738-742, 2000

86. Shimon I, Ram Z, Cohen ZR, Hadani M: Transsphenoidal surgery for Cushing's disease: endocrinological follow-up monitoring of 82 patients. Neurosurgery 51:57-62, 2002

87. Sonino N, Zielezny M, Fava GA, Fallo F, Boscaro M: Risk factors and long-term outcome in pituitary-dependent Cushing's disease. J Clin Endocrinol Metab 81:2647-2652, 1996

88. Summers SA, Nelson DH: A role for sphingolipids in producing the common features of type 2 diabetes, metabolic syndrome X, and Cushing's syndrome. Diabetes 54:591-602, 2005

89. Tyler FH, Nelson DH: Endocrinology and metabolism, in Plenk HP (ed): Medicine in the Beehive State, 1940-1990. Salt Lake City: University of Utah Press, 1992, pp 182-190

90. Tyrrell JB, Brooks RM, Fitzgerald PA, Cofoid PB, Forsham PH, Wilson CB: Cushing's disease. Selective trans-sphenoidal resection of pituitary microadenomas. N Engl J Med 298:753-758, 1978

91. Weber FP: Cutaneous striae, purpura, high blood-pressure, amenorrhea and obesity of the type sometimes connected with cortical tumors of the adrenal glands, occurring in the absence of any such tumor. Brit J Derm 38: 1, 1926

92. Weinstein M, Tyrrell B, Newton TH: The sella turcica in Nelson's syndrome. Radiology 118:363-365, 1976

93. Weiss ER, Rayyis SS, Nelson DH, Bethune JE: Evaluation of stimulation and suppression tests in the etiological diagnosis of Cushing's syndrome. Ann Intern Med 71:941-949, 1969

94. Wilson CB, Tyrrell JB, Fitzgerald PA, Pitts LH: Cushing's disease and Nelson's syndrome. Clin Neurosurg 27:19-30, 1980

95. Wislawski J, Kasperlik-Zaluska AA, Jeske W, Migdalska B, Janik J, Zaluska J, et al: Results of neurosurgical treatment by a transsphenoidal approach in 10 patients with Nelson's syndrome. J Neurosurg 62:68-71, 1985

96. Wolffenbuttel BH, Kitz K, Beuls EM: Beneficial gamma-knife radiosurgery in a patient with Nelson's syndrome. Clin Neurol Neurosurg 100:60-63, 1998

97. Yalow RS, Glick SM, Roth J, Berson SA: Radioimmunoassay of human plasma ACTH. J Clin Endocrinol Metab 24:1219-1225, 1964 


\section{Appendix: Biography of Dr. Don H. Nelson}

Don Nelson was born in Salt Lake City, Utah, in 1925. He attended the University of Utah where he received his B.A. It was while at the University of Utah Medical School that he first became interested in endocrinology research. Dr. Leo Samuels was the chairman of the Department of Biochemistry and had already established himself as an expert in steroid biochemistry. Nelson joined Samuels's laboratory after his internship, and there made substantial contributions to clinical adrenal biochemistry and physiology. He graduated from medical school in 1947 and completed an internship at Milwaukee County Hospital the following year. He then returned to the University of Utah and Dr. Samuels's laboratory as a research fellow and, later, became a research assistant professor of biochemistry. Nelson was drafted into the Navy in 1952 . He was stationed in Bethesda, Maryland, where he continued his research at the Naval Medical Research Institute.

While in Bethesda, Nelson and Hume developed a method for measuring ACTH levels in blood. In 1954, Nelson was discharged from the military and moved to Boston to start his residency in internal medicine. While at Harvard, he also completed a fellowship in endocrinology under Dr. George Thorn, and he was one of the first fellows of the Howard Hughes Medical Institute, where he used his ACTH assay to study the possible causes of Cushing syndrome. Using this assay, Nelson and his colleagues reported the case of " $\mathrm{C}$. R." and the postadrenalectomy syndrome that eventually became known as Nelson syndrome. This case report was widely read and well received. After completing his training, he joined the faculty of the Peter Bent Brigham Hospital and became the director of its Clinical Research Center. In 1959 he moved to Los Angeles to become the chief of endocrinology at the University of Southern California, where he established a new clinical research center, maintaining his ties to the Howard Hughes Medical Institute. In 1959 , with the support and urging of Dr. Wintrobe, the head of the Department of Medicine at the University of Utah, he moved back to his hometown of Salt Lake City to head the newly founded Department of Medicine at LDS Hospital. He created a strong department based on clinical and basic research. He also established an affiliation with the University of Utah, training successive generations of medical students, resident physicians, and research fellows. In 1980 he became the head of the Division of Endocrinology at the University of Utah. Dr. Nelson's bibliography speaks for itself. He was a leading scientist and clinician in endocrinology. He is now retired from the clinical practice of medicine and still lives in Salt Lake City. He continues to follow his interests in endocrinology and contribute to the body of medical knowledge. He maintains an active affiliation with the Division of Endocrinology at "the U" and continues to publish in his field. His chief contribution in recent years has been the discovery that sphingolipids mediate the biochemical effects of corticosteroids and the harmful effects that we associate with Cushing syndrome. ${ }^{35,77}$

[Dr. Nelson reviewed the historical aspects of this paper.]

Manuscript submitted June 19, 2007.

Accepted June 29, 2007.

Address reprint requests to: William T. Couldwell, M.D., Ph.D., Department of Neurosurgery, University of Utah, 175 North Medical Drive East, Salt Lake City, Utah 84132. email:neuropub@hsc.utah.edu. 